Binninger M., Dlouhy J., Müller, M., Schattmann, M., and Haghsheno, S. (2018). "Short Takt Time in Construction - A Practical Study." In: Proc. $26^{\text {th }}$ Annual Conference of the International. Group for Lean Construction (IGLC), González, V.A. (ed.), Chennai, India, pp. 1133-1143. DOI: doi.org/10.24928/2018/0472. Available at: www.iglc.net

\title{
SHORT TAKT TIME IN CONSTRUCTION - A PRACTICAL STUDY
}

\author{
Marco Binninger ${ }^{1}$, Janosch Dlouhy ${ }^{2}$, Mathias Müller ${ }^{3}$, Marco Schattmann ${ }^{4}$ \\ and Shervin Haghsheno ${ }^{5}$
}

\begin{abstract}
Takt Planning and Takt Control (TPTC), as a method of Lean Construction, has been developed over years and has increasing applications in construction practice over the last years. The collective understanding is that this method can only be implemented when there is a high level of repetition in the structure of a building project and in fact it is frequently used in such kind of projects.

A case study shows how this method was implemented on a construction site with no obvious repetition in the structure. Takt Time was reduced to a level of one hour and the single room construction site was split into small areas. A high collaborative approach of the TPTC was used. The completion time was reduced from over ten days to three days.

This paper documents the steps of the implementation, the integration of the team and subcontractors and also compares the typical approach before the optimization with the results after the Takt Time integration.
\end{abstract}

\section{KEYWORDS}

Takt Time Reduction, Takt Planning, Takt Control

\section{INTRODUCTION}

Construction projects are often characterized by long durations, being unique one-offs and having many participants. In many projects the long duration is not a significant factor as the client only expects completion by the date agreed in the contract and has made other operational arrangements for the period up to this date. However, in projects where temporary solutions are being used until the new building is completed offer significantly worse conditions, or if completion is urgent for other reasons, then project duration becomes a focus. In extreme cases, the construction process may even cause the client's operations to come to a standstill. This is especially the case for retail clients where every day of shutdown causes significant losses in turnover.

Research Fellow, Karlsruhe Institute of Technology, Germany, marco.binninger@googlemail.com Research Fellow, Karlsruhe Institute of Technology, Germany, janosch.dlouhy@bmw.de Site Manager, weisenburger bau gmbh, Germany, mathias.mueller@weisenburger.de

Department Leader, Heinrich Schmid GmbH\&Co. KG, Germany, m_schattmann@ @heinrich-schmid.de

Professor, Karlsruhe Institute of Technology, Germany, shervin.haghsheno@kit.edu 
This situation applies in the case study of this paper, which deals with a concrete situation where the effects of the methods of Takt Planning and Takt Control on the duration of a project are investigated. In this example the lever for reducing project duration is Takt Time. Through incremental steps and short-cycled repetitions project duration can be reduced while process quality is significantly increased.

\section{DEFINITION AND FOUNDATIONS}

\section{RESEARCH QUESTION}

The method is often used if there is an obvious repetition in the project. One purpose of the research was to figure out if the use of TPTC is possible for projects with nonobvious repetition in the projects. Based on this idea the paper will answer the following research question:

a) Is it possible to apply this method in projects with non-obvious repetition?

The freedom in finding and defining the repetition leads to wide latitude in setting the Takt Area and Takt Time. The paper shows a comparison of different variations, the benefits and the effects induced to the project lead-time. The second research question is: b) What is the impact of varying Takt Times on project lead-time?

\section{RESEARCH METHOD AND STRUCTURE OF THE PAPER}

Takt Planning as a method of Lean Construction is already applied in some projects worldwide e.g. Finland, Norway or Brazil. Especially in the German market there is a strong community using this method in practice. The methods used when introducing Takt are described in many publications within the community of the IGLC (Binninger et al. 2017; Dlouhy et al. 2016; Frandson et al. 2013; Haghsheno et al. 2016; Linnik \& Berghede 2013; Vatne \& Drevland 2016; Yassine et al. 2014). Planning and Control according to a standardized unit of time - the Takt Time - is a unique aspect of this method.

There are many advantages to this method in comparison to traditional time planning. For example, Takt Planning allows work to be completed at a consistent rate and allows reliable pre-planning of activities. Additionally, the Takt Plan can be built upon a mathematical-algorithmic approach and can be easily adapted with few changes to the basic parameters. For example, the construction time has a direct relation with the number of Takt Areas, Takt Time and the process sequence (waggons) shown in the following formula. Takt Time is based on the Standard Space Unit (SSU), the manpower and the performance factor. If there is only a single room construction site with no architectural and structural limits, like in the following example, the basic parameters can be varied and optimization of the project duration is possible.

In the case of retail fit-outs time plays a critical role. Using a mathematicalalgorithmic approach to build up a Takt Plan, the construction timeline can be optimized to allow earlier handover to the client. Based on this idea, the use of Takt Planning will be applied to retail fit-outs in order to be investigated and optimized.

The method described in this paper is oriented toward the 12 steps described by Binninger et al. (2017). 
This paper considers a real case study. In the following section the starting point and as-is situation will be described. In the body of the paper, execution of the project using Takt Planning will be described together with various options for construction time optimization. In the final part of this paper, one option is selected and applied to the case study. The implementation of the method and its effects will be described in full.

\section{SHORT TAKT TIME}

The method of TPTC supports the construction process, reduces waste and thereby increases productivity (Vatne \& Drevland 2016, 173). Construction duration can also be shortened actively. Friedrich et al. $(2013,50)$. name an example of a project with a reduced construction duration of $20 \%$. A case study by Frandson et al. $(2013,534)$ achieved completion in five months rather than the usual eleven by using Takt Planning. This is a time saving of $55 \%$.

The construction time of takted projects can be calculated using the following formula (Nezval 1960, 42):

\section{Construction time $=($ No. Takt Areas + No. Waggons -1$) \times$ Takt Time}

Therefore, construction time depends on the number of Takt Areas, Waggons and Takt Time. The number of waggons is strongly depending on the process and product. This parameter is only lightly influenced in the case study of this paper and does not play a significant role. Where the amount of labor (number of employees) is constant, the Takt Time and size of Takt Areas are directly related. The size of a Takt Area also determines the number of Takt Areas. Therefore, in the approach stated below the Takt Time is reduced by reducing the Takt Area size. Through reducing the size of Takt Areas, their number is increased. In the formula above, the Takt Time has a significantly higher effect on construction time than the number of Takt Areas or waggons.

In practice, varying Takt Times are used. Kaiser $(2013,113)$ names a two-day takt as the minimum Takt Time able to be used in the construction industries when taking all constraints into account. In practice a Takt Time of one week is frequently used. This is also reflected in the experiences of the authors of this paper, who have documented approximately 80 construction projects where Takt Planning was used. Of these approximately $75 \%$ used a Takt Time of one week. In contrast an example of Heinonen and Seppänen (2016) describes a Takt Time of 15 minutes. This example shows that under very specific circumstances a short Takt Time can be achieved. This idea cannot be directly applied to building projects without changing the classical approach and traditional frame conditions.

Subdivision of spaces is one way of showing the effects and interrelationships between different Takt Area sizes and Takt Time durations. The retail areas are located in a large space that due to a lack of load-bearing walls can be reconfigured as desired. Through subdivision the choice of SSU is simplified. Firstly, the biggest possible Takt Area and its required Takt Time is determined. Following this the Takt Areas and Takt Time are successively reduced until a Takt Time of 15 minutes is reached. In the view of the authors, a shorter Takt Time is difficult to execute and therefore not recommended for 
this case. The maximum possible size of a Takt Area is the entire retail area as this is also the entire working area.

Due to the short project duration and limited project scope in the case of renovating retail spaces, a weekly Takt is not practicable. A more reasonable assumption for an effective Takt Time is one day or less. Based on the research of the authors a construction with such a short Takt Time is not recorded in any IGLC paper and common literature. This paper will, however, show that it is possible to plan construction projects with a Takt Time of significantly less than one week.

\section{THE REAL CASE STUDY PROJECT}

\section{PROJECT DESCRIPTION}

The real case study is from a middle size general construction company in the south of Germany. The concepts and the results of the study are part of a master thesis. The as-is situation of the current state of the project was derived from interviews, site-observations and reviewing the project documentation. In the as-is situation, every trade has been allocated a window of time of one to three days to complete their works (or work steps) on a retail fit-out project. The works for painting, drywall and flooring are allocated a combined five-day block and not described or divided in any greater detail. Figure 1 shows the planned construction sequence of the as-is situation. This is a standard construction plan set by the client.

\begin{tabular}{|c|c|c|c|c|c|c|}
\hline day & - & 0 & 1 & 2 & 3 & 4 \\
\hline activity 1 & $\begin{array}{l}\text { last opening } \\
\text { day }\end{array}$ & $\begin{array}{c}\text { Dismantling of } \\
\text { the shelfs }\end{array}$ & $\begin{array}{c}\text { Dismantling } \\
\text { Electric }\end{array}$ & $\begin{array}{l}\text { Painting the } \\
\text { ceiling }\end{array}$ & \multicolumn{2}{|c|}{ Painter, Dry Wall, Floor } \\
\hline activity 2 & & & $\begin{array}{l}\text { Rest works } \\
\text { Dismantling of } \\
\text { the shelfs }\end{array}$ & & & \\
\hline $\begin{array}{c}\text { delivery/ extra } \\
\text { work }\end{array}$ & & $\begin{array}{c}\text { Container } \\
\text { Metall }\end{array}$ & & $\begin{array}{c}\text { Container } \\
\text { Mixed Things }\end{array}$ & Delivery Floor & \\
\hline day & 5 & 6 & 7 & 8 & 9 & 10 \\
\hline activity 1 & \multicolumn{3}{|c|}{ Painter, Dry Wall, Floor } & \multicolumn{3}{|c|}{ Electrical works } \\
\hline activity 2 & Sanitary & Sanitary & & \multicolumn{2}{|c|}{ Advertisement } & Cleaning \\
\hline $\begin{array}{c}\text { delivery/ extra } \\
\text { work }\end{array}$ & & & & $\begin{array}{c}\text { Delivery Pay } \\
\text { Desk and Light }\end{array}$ & $\begin{array}{c}\text { Delivery } \\
\text { Interior }\end{array}$ & \\
\hline
\end{tabular}

Figure 1: Construction plan of the as-is situation

Where additional works are required for a special project such as assembling drywall, additional working days will be added. In addition, electrical works must also be executed. Three days are planned for these works. In the sales area LED strips are to be fixed to the ceiling and connected to the distribution boxes. However, in the electrician's opinion, three to four workers would not need more than one day for these works.

Advertising works occur at the same time as electrical works, and has been allocated two days. The works include, for example, applying adhesive foils and signage to the shop front. Two workers were on-site for these works. Final cleaning of the retail area on 
the last day of electrical works completes the fit-out project. Altogether, this sequence results in a total of ten working days.

In the case of supplementary works, the fit-out duration is increased in accordance with the additional works required. The additional five working days for removing and replacing stock were not accounted in the ten days. The reason for this is that these works are completed by the client and not awarded to a contractor. However, this process still has the potential for shorting the project duration and causing the handover date to be earlier.

Apart from the sequencing of works, observation of the project also led to the following wastes being determined:

- Sometimes individual subcontractors set up their own intermediate storage areas. These were later hindrances to other subcontractors.

- Shelves and palettes with the shop's products were left in the space and had to be relocated many times. This causes additional transport and waiting time

- Materials were delivered by the retailer. These were not delivered at optimal times in relation to the construction sequences and caused waiting times

- There was almost no coordination between the subcontractors and this meant that they frequently hindered one another.

\section{APPROACHED USED IN THE PROJECT}

The first step was analysis of the as-is situation as described above. The main part of the as-is analysis was, on-site observations over a week-long period as well as a visit to the client and client representative.

The result was the analysis of a process by describing sequence of working steps and dependencies between them.

Additionally, the space was divided into lots during the phase of Takt Planning. Multiple options were carried out and conclusions regarding the optimal Takt Time were drawn. Theoretical calculation and estimation were carried out through multiple calibrations and adjustments by the project team. Practical work packages were devised and the Trains were established. The result was a Takt Plan that served as the basis of coordinating with subcontractors. In multiple cases the Takt Plan was adjusted and discussed with the client. Where the project duration is so short, there must be a strong focus sequence of works to ensure deliveries were organized JIT (Just in time).

The goal of this approach was to create a basic construction sequence that could be applied to other projects and individually adjusted as needed.

\section{DEVELOPMENT OF THE TAKT PLAN}

Using the as-is situation as observed results in a Takt Time of one day. This suits the actual duration of some work packages (for example dismounting electrical fixtures and fixing lights). Figure 2 shows execution of the works when using a Takt Time of one day. A working day of eight hours is assumed. 


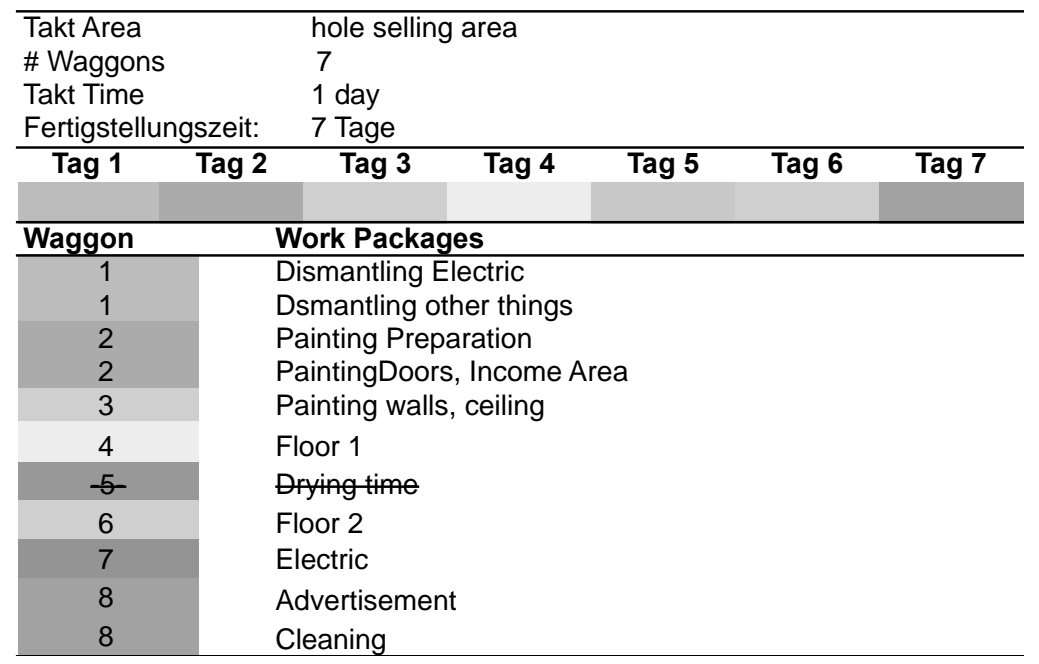

Figure 2: Takt Plan with a Takt Time of one day and the entire sales area as a single Takt Area (option 1)

For option 1, the waggon allocated for drying time is eliminated as the drying for the waggon 'Flooring 1' can occur overnight. This results in a completion time of seven working days for seven waggons.

For the following considerations, it was assumed that the 'train length' would remain as eight waggons. In the table below the Takt Time was halved in each step with the Takt Time being adapted accordingly. In the sixth step a Takt Time of 15 minutes is reached with size of each Takt Area (TA) being 1/32 of the retail area. In this instance the flooring subcontractor has 15 minutes to lay each $10 \mathrm{~m}^{2}$ of flooring for a space of $320 \mathrm{~m}^{2}$. If the tasks are tightly interlinked, this results in a theoretical finish time of less than $10 \mathrm{~h}$.

Table 1: Dividing into lots in the case of a constant amount of waggons

\begin{tabular}{ccccccccc}
\hline \# & $\begin{array}{c}\text { Takt } \\
\text { Time } \\
{[\mathrm{h}]}\end{array}$ & $\begin{array}{c}\text { Size } \\
\text { TA } \\
\text { (based } \\
\text { on 1) })\end{array}$ & \# TA & $\begin{array}{c}\# \\
\text { Waggon } \\
\text { s }\end{array}$ & $\begin{array}{c}\text { \# Waggons } \\
\text { incl. empty } \\
\text { Waggons }\end{array}$ & $\begin{array}{c}\text { Through- } \\
\text { put Time } \\
\text { [h] }\end{array}$ & $\begin{array}{c}\text { Finish } \\
\text { Time [h] }\end{array}$ & $\begin{array}{c}\text { Time } \\
\text { Improve- } \\
\text { ment [\%] }\end{array}$ \\
\hline 1$)$ & 8 & 1 & 1 & 8 & 8 & 64 & 64 & - \\
$2)$ & 4 & $1 / 2$ & 2 & 8 & 9 & 32 & 36 & 44 \\
$3)$ & 2 & $1 / 4$ & 4 & 8 & 11 & 16 & 22 & 39 \\
$4)$ & 1 & $1 / 8$ & 8 & 8 & 15 & 8 & 15 & 32 \\
$5)$ & 0,5 & $1 / 16$ & 16 & 8 & 23 & 4 & 11,5 & 23 \\
$6)$ & 0,25 & $1 / 32$ & 32 & 8 & 39 & 2 & 9,75 & 15 \\
\hline
\end{tabular}

This theoretical example shows the effect of reducing the size of lots. However, in the case of practical applications specific room conditions must be adhered to meaning that the train length of eight waggons is not implementable in practice. The drying time of eight hours is a constant, and if the Takt Time is reduced, the number of waggons will increase. Due to the drying time of eight hours remaining constant, the amount of time 
saved in each step is less significant than the number of waggons staying constant. The results are shown in table 2.

Table 2: Overview of the Takt Area reduction steps

\begin{tabular}{ccccccccc}
\hline \# & $\begin{array}{c}\text { Takt } \\
\text { Time } \\
\text { [h] }\end{array}$ & $\begin{array}{c}\text { Size TA } \\
\text { (compared } \\
\text { to 1) })\end{array}$ & $\begin{array}{c}\# \\
\text { TA }\end{array}$ & $\begin{array}{c}\# \\
\text { Waggon } \\
\text { s }\end{array}$ & $\begin{array}{c}\text { \# Waggons } \\
\text { incl. empty } \\
\text { Waggons }\end{array}$ & $\begin{array}{c}\text { Through- } \\
\text { put Time } \\
\text { [h] }\end{array}$ & $\begin{array}{c}\text { Finish } \\
\text { Time [h] }\end{array}$ & $\begin{array}{c}\text { Time } \\
\text { Improve- } \\
\text { ment [\%] }\end{array}$ \\
\hline 1$)$ & 8 & 1 & 1 & 7 & 7 & - & 56 & - \\
$2)$ & 4 & $1 / 2$ & 2 & $7-8$ & 9 & - & 36 & 36 \\
$3)$ & 2 & $1 / 4$ & 4 & 11 & 14 & 22 & 28 & 22 \\
$4)$ & 1 & $1 / 8$ & 8 & 15 & 22 & 15 & 22 & 21 \\
$5)$ & 0,5 & $1 / 16$ & 16 & 23 & 38 & 11,5 & 19 & 14 \\
$6)$ & 0,25 & $1 / 32$ & 32 & 39 & 70 & 9,75 & 17,5 & 8 \\
\hline
\end{tabular}

Reducing lot size results in five steps in total (see table 2). Compared to Step 1 the completion time is reduced by $69 \%$ to 17.5 hours. Figure 3 makes clear the significant impact of the drying time (red waggons) for the plasterer. This timeframe occupies a large part of the train and the surface area of the Takt Plan. This is the applicable size for calculating the duration of fit-out works for a Takt Time of 15 minutes.

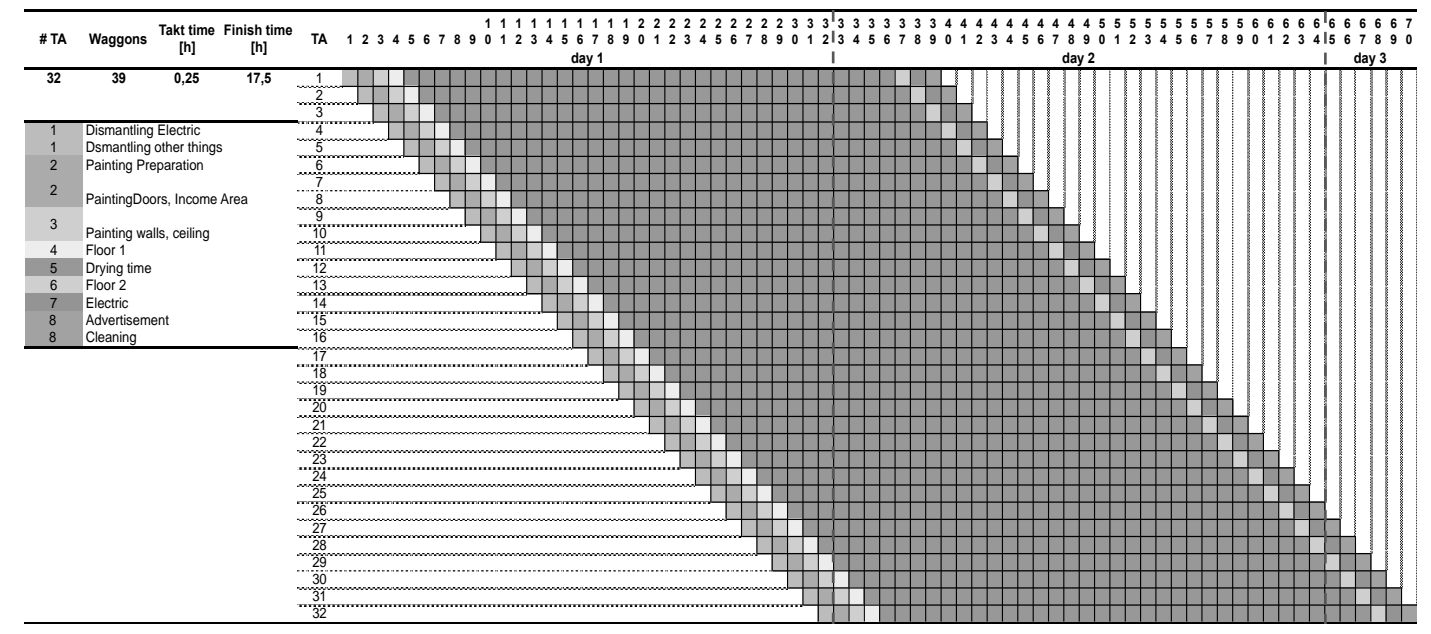

Figure 3: Takt Plan with a Tatk Time of 15 minutes and a Takt Area of 1/32 of the total area (option 6)

The size of a Takt Area is determined according to the Takt Time. Deciding a Takt Time is according to the example of lot size reduction. This showed that the length of the Takt Time has a significant effect on Takt Planning. Determining the Takt Time is based on the eight-hour working day. This leaves a buffer for increasing the working day length to nine or ten hours. A shorter Takt Time leads to a reduction in the duration of construction process. The effect relatively decreases from option 1 to option 6 because the drying time plays an important role. In this example it applies especially for a Takt Time between 15 and 30 minutes. The Takt Plan for a Takt Time of one hour is shown in 
Figure 4 as an example. With 19 waggons and 12 Takt Areas the completion time is 30 hours. This is approximately four working days.

\begin{tabular}{|c|c|c|c|c|c|c|c|c|c|c|c|c|c|c|c|c|c|c|c|c|c|c|c|c|c|c|c|c|c|c|}
\hline $\begin{array}{c}\text { \# Takt } \\
\text { Area }\end{array}$ & Waggons & $\begin{array}{c}\text { Takt time } \\
{[\mathrm{h}]}\end{array}$ & $\begin{array}{l}\text { Finish } \\
\text { Time [h] }\end{array}$ & TA & & & da & & & & 81 & & & $\begin{array}{c}1 \\
1 \\
1 \\
2 \\
\text { da) }\end{array}$ & $\begin{array}{c}1 \\
3 \\
\text { y } 2\end{array}$ & $\begin{array}{l}1 \\
4\end{array}$ & & 6 & $\begin{array}{l}1 \\
8\end{array}$ & $\begin{array}{ll}1 & 1 \\
3 & 9\end{array}$ & $\begin{array}{c}2 \\
0 \\
\text { da }\end{array}$ & $\begin{array}{c}2 \\
1 \\
y 3\end{array}$ & $\begin{array}{l}2 \\
2\end{array}$ & $\begin{array}{l}2 \\
3\end{array}$ & $\begin{array}{lll}2 & 2 \\
4 & 5\end{array}$ & $\begin{array}{l}2 \\
6\end{array}$ & $\begin{array}{l}2 \\
7\end{array}$ & $\begin{array}{c}2 \\
8 \\
\text { day }\end{array}$ & & $\begin{array}{lll}3 & 3 & 3 \\
0 & 1 & 2\end{array}$ \\
\hline 12 & 19 & 1 & 30 & 1 & \begin{tabular}{l|l}
1 \\
\end{tabular} & $2 \sqrt{3}$ & 4 & 5 & 6 & 7 & 8 & 9 & $\begin{array}{l}9 \\
9\end{array}$ & 9 & \begin{tabular}{|l|l|}
9 \\
\end{tabular} & \begin{tabular}{|l|l|}
9 & \\
\end{tabular} & \begin{tabular}{|l|l}
9 &
\end{tabular} & 9 & 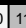 & $1 \longdiv { 1 2 }$ & & & & & & & & & & \\
\hline & & & & & 1 & 12 & 3 & 4 & 5 & 6 & 7 & 8 & 9 & 99 & 9 & 9 & 95 & 9 & 1 & \begin{tabular}{l|l|}
0 & 11 \\
\end{tabular} & 12 & & & & & & & & & \\
\hline & & & & 3 & & 1 & 2 & 3 & 4 & 5 & 6 & 7 & 8 & \begin{tabular}{|l|}
9 \\
\end{tabular} & \begin{tabular}{|l|}
9 \\
\end{tabular} & \begin{tabular}{|l|l|}
9 \\
\end{tabular} & 9 & 9 & 9 & \begin{tabular}{|l|l|}
9 & 10 \\
\end{tabular} & 11 & 12 & & & & & & & & \\
\hline & & & & 4 & & & 1 & 2 & 3 & 4 & 5 & 6 & 7 & 9 & 9 & 9 & 9 & 9 & 9 & 9 & 10 & 11 & 12 & & & & & & & \\
\hline & & & & 5 & & & & 1 & 2 & 3 & 4 & 5 & 6 & 8 & 9 & 9 & \begin{tabular}{|l|l}
9 & 5 \\
\end{tabular} & 9 & 9 & 99 & 9 & 10 & \begin{tabular}{|l|l|}
11 & 1 \\
\end{tabular} & 12 & & & & & & \\
\hline & & & & & & & & & 1 & 2 & 3 & 4 & 5 & 7 & 8 & 9 & \begin{tabular}{|l|l}
9 & 5 \\
\end{tabular} & 9 & 9 & 9 & 9 & 9 & \begin{tabular}{|l|l|}
10 & 1 \\
\end{tabular} & 11 & 12 & & & & & \\
\hline & & & & & & & & & & 1 & 2 & 3 & 4 & 56 & 7 & 8 & \begin{tabular}{|l|l}
9 & 5 \\
\end{tabular} & 9 & 9 & 9 & 9 & 9 & \begin{tabular}{|l|l}
9 & 1 \\
\end{tabular} & 10 & 1112 & & & & & \\
\hline & & & & & & & & & & & 1 & 2 & 3 & 45 & 6 & \begin{tabular}{|l|l}
7 \\
\end{tabular} & \begin{tabular}{l|c}
8 & 5 \\
\end{tabular} & 95 & 9 & 9 & 9 & \begin{tabular}{l|l}
9 \\
\end{tabular} & 9 & 9 & \begin{tabular}{l|l}
10 & 11 \\
10
\end{tabular} & \begin{tabular}{l|l}
112 \\
\end{tabular} & & & & \\
\hline & & & & 9 & & & & & & & 4 & 1 & \begin{tabular}{l|l}
2 & 3 \\
\end{tabular} & \begin{tabular}{|l|l|}
3 & 4 \\
\end{tabular} & \begin{tabular}{|l|}
5 \\
\end{tabular} & \begin{tabular}{|l|}
6 \\
\end{tabular} & \begin{tabular}{|l|l}
7 & \multicolumn{1}{|c|}{} \\
\end{tabular} & 8 & 9 & 9 & 9 & 9 & 9 & 9 & \begin{tabular}{l|l|l}
9 & 10 \\
\end{tabular} & \begin{tabular}{l|l}
0 & 11
\end{tabular} & 12 & & & \\
\hline & & & & 10 & & & & & & & & 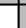 & 1 & \begin{tabular}{|l|l|}
2 & 3
\end{tabular} & 4 & 5 & 6 & 7 & 9 & 9 & 9 & 9 & 9 & 9 & 9 & 10 & 11 & 12 & & \\
\hline & & & & $=11$ & & & & & & & $=$ & & 1 & 12 & 3 & 4 & 5 & 6 & 8 & 3 & 9 & 9 & 9 & 9 & 9 & 9 & 10 & 11 & 12 & \\
\hline & & & & 12 & & & & & & & 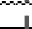 & & & 1 & 2 & \begin{tabular}{|l|l}
3 \\
\end{tabular} & \begin{tabular}{|l|l}
4 \\
\end{tabular} & 5 & $\sqrt{7}$ & 8 & 9 & \begin{tabular}{|l|}
9 \\
\end{tabular} & \begin{tabular}{|l|l}
9 & 5 \\
\end{tabular} & \begin{tabular}{l|l|}
9 & 9 \\
\end{tabular} & $\overline{9}$ & 9 & $\overline{9}$ & \begin{tabular}{|l|l|}
10 & \\
\end{tabular} & \begin{tabular}{l|l}
11 & 12 \\
\end{tabular} & \\
\hline & ggons & & Work Pac & rage & & & & & & & & & $\operatorname{lags}$ & gon & & & & & & & $\overline{\text { Wor }}$ & rk $P$ & Pack & kage & & & & & & \\
\hline & W1 & & Dismantling & Electric & & & & & & & & & W & & & & & & & & & ying & $\mathrm{g}$ Tim & & & & & & & \\
\hline & W2 & & Osmantling oth & er things & & & & & & & & & W & & & & & & & & & & or 2 & & & & & & & \\
\hline & W3 & & Painting Pre & aration & & & & & & & & & W & & & & & & & & & ying & $\mathrm{g}$ Tim & & & & & & & \\
\hline & W4 & & Painting walls & , ceiling & & & & & & & & & W & & & & & & & & & & or 3 & & & & & & & \\
\hline & W5 & & Lights & & & & & & & & & & W & & & & & & & & & & ctric & & & & & & & \\
\hline & W6 & & Floor & & & & & & & & & & W & 12 & & & & & & & & & aning & & & & & & & \\
\hline
\end{tabular}

Figure 4: Takt Plan with a Takt Time of one hour and 12 Takt Areas

\section{EXECUTION}

A Takt Time of one hour was selected for the example project. Using such a short Takt Time means there are more short-cycled quality control inspections, the completion time is shorter and the learning curve is steeper for all participants. The contractors can move between the waggons allocated to them, and thereby use time saved on the waggons completed ahead of schedule to support any waggons behind schedule. The contractor was not willing to risk an even shorter Takt Time in the first project in which it was trialled. This was in conjunction with the idea to hold short meetings at the end of every Takt Time to discuss improvements to the process. In theory the project variables can be scaled up and down without any limits. In practice the Takt Areas must be sized and allocated so as to fit with the geometry of the building. The project in this case was divided into the following Takt Areas:

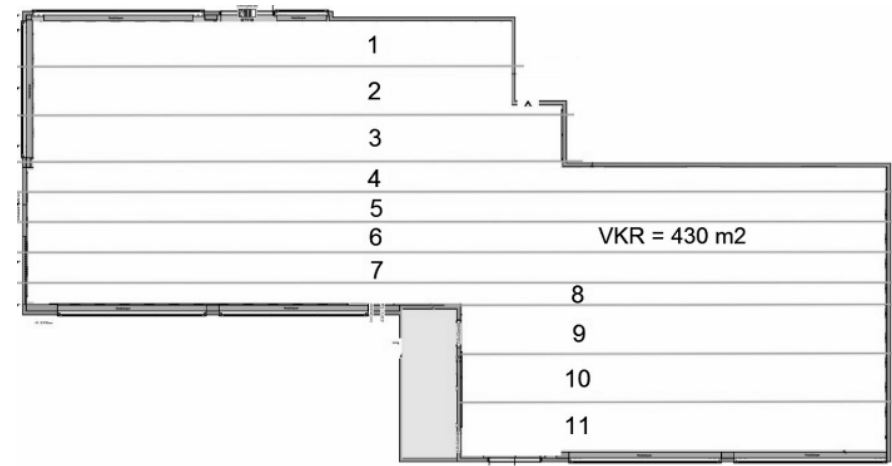

Figure 5: Division of the project into Takt Areas

The subcontractors were introduced to the project, and the test began in December 2016. The construction manager and foremen set aside three days to intensively supervise 
and document the project. The following pictures give an impression of how the project unfolded.

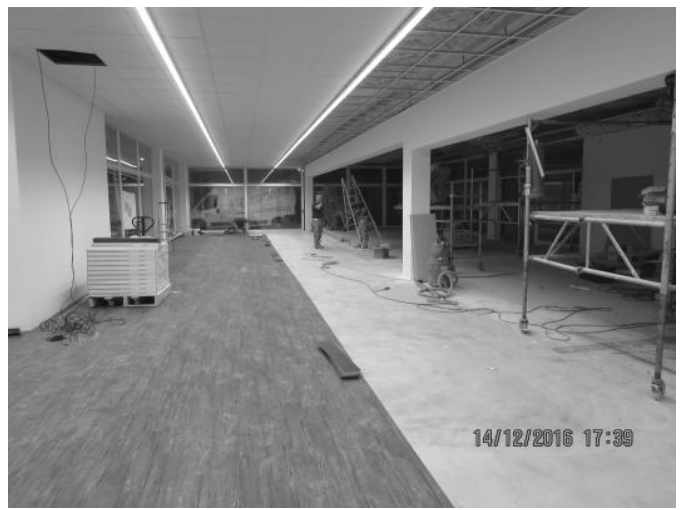

Figure 6: Takt Plan with Post-Its (left side) and impression of the construction site (right side)

The left-hand side of the figure represents the information board used during meetings. The right-hand picture shows a tightly integrated project sequence and its allocation into linear Takt Areas.

\section{RESULTS}

The results achieved have matched the predicted three-day duration of construction. Hereby the pilot project was able to achieve a $70 \%$ reduction in construction duration. This is however, not the only effect. At first the subcontractors were very critical of the new method of execution. During contract negotiations some subcontractors expressed concerns that their own effectiveness would be compromised by such a tightly integrated construction sequence. The construction manager also voiced concerns. The manager accepted the risk and promised the subcontractors full payment over three days even if they did not have any work for parts of these days. This message and the participation and active involvement of the manager gave the project an added level of importance as well as a clear signal to the subcontractors. By the end of the first day all participants understood that this construction site worked in a different way to usual construction sites and a small competition emerged. The subcontractors were surprised how seamlessly the project was run and were pleased that their Takt Area was free from other subcontractors.

The learning curve was also very steep. Due to an unsealed flat roof construction the sequence of the Takt Areas had to be significantly rearranged shortly after construction began. This change was incorporated very quickly and without problems. The Takt Plan helped with the adjustment and enabled greater transparency. During the course of the first day the construction manager had to make frequent interventions. This required a high level of management effort, as the construction sequence was new to the subcontractors. They worked in an uncoordinated way and thereby overestimated their working capacity. At the beginning of the project the level of understanding for waste was very low, and there was little improvement over the three days. One reason for the 
overestimation was that the workers achieved $100 \%$ of the required work despite constant interruptions from phone calls and additional coordination effort.

In summary, it could be determined that in the pilot project the using Takt Planning enabled a significant reduction in construction duration. Through close supervision and comprehensive documentation additional potential was uncovered.

\section{CONCLUSION AND OUTLOOK}

The paper shows an outstanding practical example of TPTC under project conditions, which were apparently not perfectly suitable for takted projects. The project in the case study had obviously non-repetition, because there was only one single room. The case study shows that it was possible to find repetitions, if the process, time and space are divided detailed enough (research question a).

A Takt Time reduction has a highly positive impact of the project duration (research question b). But the scalability is limited due to the increasing impact of drying times.

The company Heinrich Schmid must be highly commended whose management was a driving force in this project. The positive effects of the pilot project is due to a higher amount of preparation work which must be optimized in future projects

The uncovered potential must also be developed further as this would allow the construction phases to be even more tightly integrated. The first half of the sales areas could be handed over in half of the previous total construction time. The retailers can thereby set up their shops significantly earlier than the previous case. Alternatively, this can be integrated into the Takt Plan used by the client to significantly reduce the amount of time needed for finishing the circulation areas.

\section{REFERENCES}

Binninger, Marco; Dlouhy, Janosch; Haghsheno, Shervin (2017), „Technical Takt Planning and Takt Control in Construction.“. In: Proceedings of the 25th Annual Conference of the International Group for Lean Construction. Heraklion, Greece, p. 605-612.

Dlouhy, Janosch; Binninger, Marco; Oprach, Svenja; u. a. (2016), „Three-Level Method of Takt Planning and Takt Control - a New Approach for Designing Production Systems in Construction“. In: Proceedings of the 24th Annual Conference of the International Group for Lean Construction. Boston, USA.

Frandson, Adam; Berghede, Klas; Tommelein, Iris D. (2013), „Takt Time Planning for Construction of Exterior Cladding“. In: Proceedings of the 21th Annual Conference of the International Group for Lean Construction. Forteleza, Brazil, p. 527-536.

Friedrich, Till; Meijnen, Peter; Schriewersmann, Florian (2013), „Lean Construction - die Übertragung der Erfolgsmodelle aus der Automobilindustrie“ [Lean Construction The transfer of successful models in the automotive industry]. In: Motzko, Christoph (Hrsg.) Praxis des Bauprozessmanagements. [Practice of construction management. Control deadlines, costs and quality reliable]. Weinheim, Germany: Wiley-VCH 
Verlag GmbH \& Co. KGaA, p. 37-52, DOI: 10.1002/9783433602973.ch2. ISBN: 978-3-433-60297-3

Haghsheno, Shervin; Binninger, Marco; Dlouhy, Janosch; u. a. (2016), „History and Theoretical Foundations of Takt Planning and Takt Control“". In: Proceedings of the 24th Annual Conference of the International Group for Lean Construction. Boston, USA.

Heinonen, Aleksi; Seppänen, Olli (2016), „,Takt Time Planning: Lessons for Construction Industry from a Cruise Ship Cabin Refurbishment Case Study“. In.: Proceedings of the 24th Annual Conference of the International Group for Lean Construction. Boston, USA.

Kaiser, Jörg (2013), Lean Process Management in der operativen Bauabwicklung. [Lean Process Management in oprational site management] Darmstadt: Inst. für Baubetrieb (Schriftenreihe des Instituts für Baubetrieb). ISBN: 978-3-941925-14-4

Linnik, Meeli; Berghede, Klas (2013), „An Experiment in Takt Time Planning Applied to Non-Repetitive Work“. In: In: Proceedings of the 21th Annual Conference of the International Group for Lean Construction. Forteleza, p. 609-618.

Nezval, Jiri (1960), "Grundlagen der Fließfertigung in der Bauproduktion". [Fundamentals of flow production in construction] 1. Auflage. Verlag für Bauwesen Berlin.

Vatne, Mats Erik; Drevland, Frode (2016), „Practical Benefits of Using Takt Time Planning: A Case Study“. In.: In: Proceedings of the 24th Annual Conference of the International Group for Lean Construction. Boston, USA, p. 173-182.

Yassine, Tarek; Bacha, Mohammad Bassel Saleh; Fayek, Farah; u. a. (2014), „Implementing Takt-Time Planning in Construction to Improve Work Flow“. In: Proceedings of the 22th Annual Conference of the International Group for Lean Construction. Oslo, Norway, p. 23-27. 